\title{
Inés y la Alegría: Women in the Resistance against Franco
}

\author{
Ana Pociello Sampériz \\ Instructor of Spanish. PhD Candidate \\ Department of Hispanic Studies \\ University of Kentucky, Lexington, Ky. USA
}

\section{Doi:10.5901/mjss.2013.v4n9p262}

\begin{abstract}
This paper examines the normalization of violence during the Spanish Civil War (1936-1939) and immediate postwar era through the lens of historical memory, focusing more specifically on anti-Francoist guerrilla women: one of the more silenced social realities until the end of the 20th century. I argue that the novel Inés y la Alegria, by Almudena Grandes (2010) denounces Francoism's repercussion to present-day democracy and silenced society. Using an intersectional analytical framework constituted by concepts by Cynthia Enloe, Zillah Eisenstein, Walter Benjamin and Johan Galtung, I analyze Grandes' novel considering a variety of issues: the militarization of women, women's power and empowerment, connections between the state and violence in the Spanish case, and stereotypes, myths and realities implied on the role of anti-Francoist militiawomen. I argue that the author's goal is to spread the story in an attempt to recover the voices of the defeated who couldn't tell their story due to the Francoist repression; considering as well the repercussions of such repression still visible today in Spanish society.
\end{abstract}

During the Spanish Civil War and immediate postwar era, particularly during the 1940s and 1950s, Spaniards suffered direct and indirect violence by Franco's dictatorship. Some of this violence involved violation of human rights by the state, which prosecuted and killed the anti-Francoist guerrilla, using government's propaganda to criminalize them. Not only do the crimes against humanity committed by the fascist government still remain unprosecuted, but also Francoism had a deep impact on Spanish society, starting by the gender implications and the normalization of violence. As a result, there was an implicit silence pact, affecting the transition to democracy and the current society. In this paper, I examine the connections between women and violence in the Spanish Civil War and immediate postwar era. More specifically, I examine women in the anti-Francoist guerrilla or maquis that showed either a pacifist or an armed resistance strategy against Franco. My discussion examines the normalization of violence through the lens of historical memory, analyzing Grandes' purpose while writing the novel Inés y la alegría (2010). I will use the theorization of peace and militarization as put forth by Cynthia Enloe and Zillah Eisenstein. Additionally, I use Walter Benjamin's reflections on violence, in dialogue with Enloe and Eisenstein's concepts, in order to apply the connection between the state and violence to the Spanish case, with a gendered approach. The results indicate how the state has shaped democracy with terror. This paper is a part of a bigger project, where I will continue my research with a deeper analysis of the power relations and the gender implications on Inés y la alegría.

As it is well known, the Spanish Civil War (1936-1939) started after a military coup by Franco's forces against the elected government of the Second Spanish Republic, and became notable for the passion and political division it inspired. Atrocities were committed by both sides in the war: tens of thousands of civilians on both sides were killed for their political or religious views, and after the war's conclusion in 1939, those associated with the losing Republicans were persecuted by the victorious Francoist rebels. The war ended with the victory of the rebels, the overthrow of the democratically elected government, and the exile of thousands of left-leaning Spaniards, many of whom fled to refugee camps in Southern France. A dictatorship led by General Francisco Franco was established, and a new era of repression started, because the winners were going to celebrate their victory "aunque fuera sobre las ruinas, aunque fuera sobre un millón de muertos" (Tusquets, 2008, p. 24). However, there were still forms of resistance to the new regime: the maquis or anti-Francoist guerrilla were, for the most part, armed men that ran away into the mountains in order to escape the Francoist repression and to get organized in coordinated guerrilla movements. To survive, they made use of little thefts, which caused a stigmatization as bandits by the Francoist regime. They had the help of enlaces or liaisons: friends and relatives that provided the maquis with food, guns, clothes, medicine, and etcetera. Those friends and relatives where mostly women, since many leftist men were already fighting, in jail, exiled or dead, while plenty of women became the breadwinners for their families during the postwar era. 
In the Francoist Spain most of the women (with the exception of privileged socioeconomic classes, whose women had a little more freedom yet still being subjugated by the strong patriarchal structure of the society) didn't participate in culture, economy or society, unlike men. Additionally women had to stay at home, and if they worked, they had to adopt professions "appropriate" for a woman, such as teachers or nurses. However, when the Civil War started years earlier and thousands of militiamen joined the front, a big part of the feminine sector had to participate in production en masse, filling the vacant positions left by men that were incorporating to the fight. Mothers became the breadwinners for the family, and many of them were pregnant when the father of their baby left to the exile or to the battle. Plenty of women joined the front: the Republican was the second army (after Russia in 1917) that incorporated women to the militia. Political forces were asking for women's mobilization; orators like Dolores Ibárruri -la Pasionaria- (PCE, Spanish Communist Party) or Federica Montseny (C.N.T, National Confederation of Labor) addressed the women asking for their incorporation to the antifascist fight. Militiawomen became a referent for many countries' leftist organizations before World War II, and it was a big step for the gender fight in Spain and the rest of the world. The Republican side presented a gendered imagery with the innovative image of the young and pretty militiawoman, who marched to the war fronts, with a rifle. Next to this image was also represented the woman victim of Francoism, the mother, who defends her children and, inconsolable, demands justice for the loss of her relatives and urges for the participation on the fight. According to sources such as Alcalde's book Las mujeres en el franquismo and the testimonies from Tomasa Cuevas' book Prison of Women: Testimonies of War and Resistance in Spain, 1939-1975, most of the women that joined the militia were extremely young, about sixteen years old, recruited by communist and anarchist organizations. The young age of the militiawoman connects with the few options they had on a warlike context. The motivations that they had for the battle were different: personal convictions, revenge for a relative's death, etcetera. There are also cases documented in Neus Catalá's compilation of testimonies about women going to the battle front with their boyfriends or husbands. There were also mothers that joined the fight with their sons. In the first months of the war thousands of women participated in the fortification of barricades, the care of the wound, the organization of assistance at the rearguard, the professional and cultural formation, the organization of sewing workshops, or in the munitions factories. In Spain no positive discrimination was made when a woman got arrested and they ran the same risks as the men of their family that were already arrested, tortured or executed. And just for the fact of having militant friends and relatives, the weight of justice fall on them plenty of times, particularly for the enlaces. Enlaces became the scapegoat that paid the consequences when a maquis patrol escaped from the Civil Guard. The enlaces or liaisons were frequently relatives or friends form the maquis, which automatically made them the target of tortures, interrogatories and punishments from diverse nature, being imprisonment, rape, torture and execution among them. This punitive system did not just apply to the enlaces, but also to girlfriends, wives, relatives and insurgents, most of them women that were routinely arrested and punished because of the connection with the anti-Francoist guerrilla. Antonio Muñoz Molina asserts about the gender implications: "Las mujeres pueden unirse al número de víctimas absolutas, los que eran condenados no por sus actos ni por sus palabras, no por profesar una religión o una ideología, no por arrojar octavillas que no iban a influir sobre nadie ni por echarse al monte sin ropas ni calzado de invierno y sin más armas que una pistolilla ridícula, sino por el simple hecho de haber nacido". (Muñoz Molina, 2001, p. 390-1)

It is important to note that for the Nationalist side, women fighting in the military were considered as the antithesis of what a decent woman should do (taking care of the wound, feeding their children, etc.). These women suffered the repression when they were captured: between 1939 and 1940 there were 30,000 women in the overcrowded Ventas prison in Madrid, one of many prisons with female prisoners. The repression continued after the war for the Republican women inside and outside the jail, resulting sometimes on gendered punishments, such as shaving the women's head or in the case of the female inmates of Franco's prisons, getting their nipples burned with cigarettes and connected to electric shocks or had their belly kicked in the case of pregnant women. Some of the other disgusting techniques used by the Francoist police against women out if jail were also torture or forcing them to drink castor oil and making them walk around their village so they would be ashamed of the consequences. The female inmates of Franco's prisons had to be naked for hours under cold showers. Particularly during interrogations, they were beaten, hanged from columns, they were raped, tortured and there were even cases of necrophilia after the execution of some female inmates by firing squad (the most common method used by Franco's police or Guardia Civil).

At the end of the Civil War and during the rest of the 20th century, cultural and literary productions about the fratricide fight and the immediate postwar were limited. First, due to the iron censorship from Franco's regime, and years later, when Franco died and the transition to democracy started, such limitations lied in an implicit silence pact among all the Spaniards. The pact resulted in a collective amnesia for the victims, the history, and even the crimes against humanity that still remain unprosecuted nowadays. Therefore, the survivor's generation of the Spanish Civil War is 
disappearing, and the effort of maintaining the historical memory from those years and of making the history clearer with new information and new perspectives for the new generations has brought the attention of critique in Spain and outside the country. The culmination of such interest has been the creation in 2000 of Asociación para la Recuperación de la Memoria Histórica, and the approval in 2007 of Ley de Memoria Histórica. Despite the numerous exhumations and social consciousness work developed by this organization, the recovery of a Spain crippled and oppressed by the Francoism's repression, by silence and oblivion, is still slow and painful.

Thus we can state that starting in the year 2000 there is a cultural explosion that overpowers the silence pact mentioned previously, encouraged by the narrative urgency that means many authors are trying to spread the silenced history before all the protagonists die. Many novels are an example of this, such as Soldados de Salamina (2001) by Javier Cercas, which deals with the topic of the reconstruction of the historical memory and the process of dealing with the past. Likewise, during the historical memory boom, topics silenced before start to be treated more deeply, like the history of maquis, represented in La noche de los cuatro caminos (2001) by Andrés Trapiello, and Maquis, historia de la guerrilla antifranquista (2002), by the historian Secundino Serrano. The monograph La resistencia armada contra Franco: Tragedia del maquis y la guerrilla, by Francisco Moreno Gómez, and La última gesta. Los republicanos que vencieron a Hitler, by Serrano, are the only two sources with information about the 1944 maquis campaign, directed by PCE, which Grandes fictionalizes in the novel object of my study. In the last couple of years, women have been represented from different fields, unexplored before in the cultural and literary context. However, the role of women allows new explorations from the perspective of historical memory, such as the Republican women in the militia (as an example, La capitana, by Elsa Osorio, 2012). It is also relevant the representation of the Republican women in Franco's jails, like the novel La voz dormida, by Dulce Chacón or Las trece rosas (2003) by Jesús Ferreiro. On the other hand, Ana Ramírez Cañil tells a story about women that acted as enlaces or liaisons, getting involved with the anti-Francoist guerrilla in her novel La mujer del maquis (2008). Inés y la alegría (2010) by Almudena Grandes, is another example of feminine resistance to Franco's regime through the fight with the maquis, as well as the novel I will analyze. The representation of the anti-Francoist guerrilla and enlaces has spread to cultural products such as cinema, with films like El laberinto del fauno (2006) by Guillermo del Toro, and Silencio roto (2001) by Montxo Armendáriz.

It is necessary to consider the work of critics about the women's role through the perspective of historical memory, since there is not much bibliography dealing with the topic. Critique has primarily focused on the study of Republican women, due to the need to recover the past of the victims that are not recognized as such. Gina Herrmann explores this topic in her article "Voices of the Vanquished: Leftist Women and the Spanish Civil War" (2003). Herrmann works with the transmission of the transgenerational heritage of militancy and ideological beliefs, concept also worked by Jo Labanyi. Herrmann also refers to the relevance of the narrative urgency used by post memory generations to avoid the perpetuation of the collective amnesia about their leftists' militant grandmothers. José Romera Castillo has also worked with the recovery of the historical memory for the Republican women, in his article "La memoria histórica de algunas mujeres antifranquistas" (2009), which will be relevant for the sociological field of my study.

The Spanish case can be connected with Enloe's book Maneuvers, where she states that militarization and the privileging of masculinity are both products not only of amorphous cultural beliefs but also deliberate decisions. Additionally, Zillah Eisenstein exposes with Against Empire: Feminisms, Racism and the West the silenced and misrepresented histories of the US wars of terror, uncovering the relations and histories of power, in order to see as much as possible. She argues that rape is one weapon of war, but so are dress codes (burqas and bikinis), sex trafficking (from "comfort women" to other forms of "rest and recreation" for soldiers), harassment of military women, and militarized masculinity. Another idea that I consider particularly useful is that the human rights for Eisenstein are universal, humanly given to anyone who is human. From this position the author explains how the United States' talk on human rights is a type of rhetoric and how ideologies of liberal democracy and its propagators manipulate and control the human rights discourse. Applied to my research this idea can also be used to explain the loss of identity and dehumanization of the leftist rojos that were repressed by Franco's regime. There is a connection too with the manipulation and control of the human rights discourse by the Spanish government. Fascists used both religion and bills, like the "Ley de bandidaje y terrorismo" that equated the Spanish anti-fascist guerrilla with criminals that must be hunted in front of the eyes of their fellow citizens, while many of the same warriors were considered heroes in France for fighting against Nazism after the Spanish Civil War. An example of the exercise of this control can be seen in Inés y la alegría: Franco hides information to the nation about what it could have led to his failure: a reconquer of Spain by the Republic. In addition, Walter Benjamin's Critique of Violence is especially relevant for the Spanish case, because it helps to explain the underlying violence in the political change to democracy. Through a discussion of the connections between natural and positive law, Benjamin sets the stage for a justification of the uses of violence (general strike or capital punishment), 
and of violence as a fact of nature or as a result of history.

Even though I am going to focus in state and anti-state violence, it must be highlighted how common the mention of anti-state violence in media is compared to the mention of state violence. I also want to emphasize that the Spanish Civil War and postwar was a scenario of different types of violence, starting with state violence, but also institutional violence, if we consider the abuses by the Guardia Civil to prisoners and civilians. As Gina Herrmann argues, it is paradoxical how free expression and the democratic open flow of information creates the perception of a violent society, while the dictatorship projected an image of peace and order at the same time that it incarcerated, tortured and executed thousands of citizens. The dictatorship was able to project this peaceful imaginary because it held the monopoly of force and signification by controlling information, denying public access to references of violence. Fernández de Alba says on the introduction of Herrmann's book in 2003 that "recent access to such information has allowed historians to begin to reconstruct the silenced political violence of the dictatorial regime and to create a genealogy of suffering that, beyond all justifications, is hard to contest" ( p. 2). On the other hand, Johan Galtung's structural violence also happened among civilians, if we consider the lack of economic resources that Spain suffered after a three year war, where the money from the previous government of the Republic was worth nothing, and ration books were necessary in order to get food. This shows that even when there is no direct violence, violence still exists through the social injustice. Those unjust social structures that are the root of the structural violence are taken for granted or seen as natural by those in power, as it is the case of Francoist government position regarding the poverty and hunger isolating Spain for years. Damián González Madrid provides an account of the political violence of Franco's regime in his article "Violencia política y dictadura franquista." The author forwards an obvious yet disturbing idea for contemporary Spain: that repression during the Francoist dictatorship was conducted with the acquiescence and collaboration of the population, an aspect widely explored by Grandes. After all, we can't forget that state and law are violent per definition.

Grandes' novel intertwines stories about different people involved in the maquis' attempt to reconquer Spain in 1944, revealing the gender and power structures with the backdrop of the normalization of violence throughout the female characters, particularly Dolores Ibárruri (La Pasionaria) and the protagonist Inés. The author presents the character of Adela, married to Ricardo, Inés' brother and chief of Falange in Lérida, as a juxtaposition of the decent women versus the rebels that constitute the previous characters, showing us therefore some of the implications of the society of those times on the women's lives. Despite of that, Adela ends up rebelling against the system herself by visiting Inés and Pasionaria in Toulouse, and even getting a lover and enjoying openly of her sexuality, by also stopping to go to church and asking Inés to send her frequently condoms, in order to avoid the shame of being caught with them while crossing the border.

Since we consider the function of the novel to be restoring the lost memory, it is important to state that, according to Grandes (2010), "La Historia con mayúscula la escriben siempre los vencedores, pero su versión no tiene por qué ser eterna" (p. 457). For the author, Spain is an abnormal country since it hasn't integrated the failure of the people who fought for freedom on the national pride. Grandes regrets that nobody has ever conducted a census with Arán valley invaders, or compared the list with the names of the men who entered into the country for the invasion and the men who left. The author decided to solve the lack of information by developing her own version of the invasion in a three-axis novel: Inés' story, Galán's story and the shorter chapters with the title in parenthesis, that are at the end of each chapter. The first chapter tells some real historical events to provide us with the context and explores how power is operated among the representatives of the PCE, those who decide the future of the invasion and therefore, of the maquis. These power structures will be altered soon when gender issues, love and manipulation show up among the people involved on deciding upon the maquis' destiny: "las páginas de la novela, como los días de la realidad, están perforadas por túneles y atajos que permiten que los habitantes de las alturas del poder desciendan, de vez en cuando, hasta el nivel del suelo." (Grandes, 2010, p. 499). On the other hand, the other two axes of the novel are completed with a fiction story that interweaves real characters and facts with the author's version of the story, due to the lack of information about the official history. The chapters titled in parentheses are a way for the author to make her voice being heard, as a justification for the recognition that Grandes is demanding for the real characters whose story has been erased by the winners. In fact, testimonies from Franco's sister, Pilar Franco Bahamonde, make clear that the only moment she has seen her brother out of his mind was in 1944, when the maquis tried to reconquer Spain. Francisco Franco hides the truth from the rest of the Spaniards in order to perpetuate the order of the military controlled state that he was trying to establish by then.

It is important to emphasize the contrast between the regime's conception of maquis as criminals and the vision that Grandes offers in the novel about the resistance movement or guerrilla. Here most of the resistance against Franco is peaceful, trying to avoid violence, repression and revenge, as we can see on the instructions that el Lobo, the colonel, 
gives to his militiamen, giving emphasis to his men's good behavior, most likely in order to get rid of the stigmatization the regime had given them as criminals:

\begin{abstract}
No volvemos a España para tomar represalias, ¿entendido? [...] Los únicos fusilamientos que estoy dispuesto a firmar son los de los soldados que se atrevan a tomarse la justicia por su mano, [...] No voy a consentir, de ninguna manera, ejecuciones sumarias, torturas, ni malos tratos a civiles, sean quienes sean, hayan hecho lo que hayan hecho, o lo reclame quien lo reclame con las lágrimas temblándole en los ojos.......] Por muy guapa que sea, por muy buena que esté, y por muy bien que haga las cosas que mejor sepa hacer. (Grandes, 2010, p. 239)
\end{abstract}

The maquis' fraternity, despite age, birthplaces and personality, is a strong bond that we can see throughout the whole novel. One example is when the chief of the guerrilla gives total priority to the evacuation from Spain of two of his men that resulted injured by a grenade in the attempt of invasion of Arán. The novel also shows how such fraternity happened among gender and class barriers, but always with the backdrop of the Spanish postwar era characteristic mistrust. This fraternity connects with the concept of Benedict Anderson developed on a book of the same name, Imagined communities, even though the concept wouldn't be explored until 1983. After all, the re-instauration of the Republic in a Francoist Spain constitutes an imagined political community among the maquis and enlaces who fought together against Nazism (such as Galán, Lobo, the upper-class Inés or Comprendes) and now are on the way to rescue their nation, with 8,000 other guerrilleros that couldn't be happier to hear from their superiors that they are going to Spain to overthrow Franco.

On the other hand, Inés, whose family is among Madrid's upper-class, doesn't follow the patriarchal rules of society, "Si yo fuera hombre, me habría alistado" (Grandes, 2010, p. 56), and rebels against all the values that were taught to her by installing an office of Socorro Rojo at her home during the war. Later, her "political responsible", a militiamen called Pedro, denounces her, and therefore she is arrested and imprisoned in Ventas, where she was:

Otra presa anónima entre miles de reclusas de la misma condición, abandonadas a su suerte en unas condiciones más duras que la intemperie. En Ventas no cabiamos, no teniamos sitio para dormir estiradas, ni un trozo de muro para apoyar la espalda al sentarnos, ni espacio en el patio para pasear. No había aire suficiente para todas en aquel patio que olía a muchedumbre, a invernadero, al sudor irremediable de miles de cuerpos humillados a su propia suciedad. (Grandes, 2010, p. 63).

The omission of any insinuation of torture, rape or physical violence on Inés' version of the imprisonment is shocking, since those practices were systematic in the penitentiary institutions. It is even more bizarre considering that she gives plenty of details later in the novel when describing similar episodes. We can understand that this omission occurs as an attempt by the main character to keep her dignity, and to avoid further public humiliation, due to the similar cases found in testimonies from Tomasa Cuevas' book. The only violent punitive measures that Inés mentions are the daily shootings by fire squads that took place against the wall of Cementerio del Este, and whose shots acted as alarm clock for the inmates: "Todos los días escuchábamos los tiros de gracia, sueltos, aislados, y se nos llenaban los ojos de lágrimas, y nos moríamos de frío durante un instante en el que dejábamos de sentir el calor y nuestro sufrimiento, el hambre, la sed, el miedo, el cansancio" (Grandes, 2010, p. 64). However, what awaits Inés after Ventas is even worse for her, until the point that she tries to commit suicide: her brother Ricardo locks her on a convent. We can observe the "Othering" suffered by Inés for being a woman who doesn't follow the rules of femininity stated on a mysoginist society: because of the patriarchal system of the postwar Spain, Ricardo is the one in charge of taking decisions, as her brother. Then Ricardo sends Inés to Pont de Suert, a village in the Catalan Pyrenees where he lives with his wife Adela and their children, not giving Inés any choice or opportunity to question his orders. This concept links with Zillah Eisenstein ideas when developing the concept of women's "Othering"; for Eisenstein, war is the extreme example of the terror visited on women and their families by a "systematic patriarchal structuring of racialized, sexualized, global exploitation" (Eisenstein, 2004, p.183) and by fundamentalist misogyny. Another example is that, when the rumors about the imminent invasion start spreading, Ricardo decides to send his family to Madrid, except for his sister, who will go again to live on a convent. But Inés escapes to the village of Bosots to meet the maquis, with a horse, three thousand pesetas and five kilos of rosquillas, with the hope of finding Spain's saviors, but it is also relevant to consider that the military has always been a patriarchal institution. As Eisenstein stated on the second chapter of her book Against Empire, there were women considered war followers, and this is what Inés is considered to be at the very beginning. The concept of the war followers is closely related to the comfort women developed by Enloe on the third chapter of her book Maneuvers, called "The prostitute, the colonel and the nationalist". Enloe explores the cases of women raped by soldiers, where sexuality and militarism have been intertwined. Indeed, the author argues that ideologies of militarism and sexuality "have shaped 
the social order of military base towns and the lives of women in those towns." (Enloe, 2000, p. 51) On the other hand, women try, as feminists, to alter the patriarchal practices, which reflects in Inés' actions. But Inés' case is slightly different: she sleeps with Captain Galán, which reinforces her status by giving her the best room in the major's house occupied by the maquis. Inés also takes control of the kitchen, getting a power that she never had before. Besides constituting a means of achieving empowerment, cooking also represents a way Inés can escape from the repression and stop thinking and worrying about all her problems.

Falange's commanding officer Garrido, a friend of Ricardo, represents the brutality of the patriarchal institutions, and constitutes the best example of direct physical and psychological violence against Inés, who belongs to the leftist side, and therefore, she is one of the losers of the war, as he says: "Deberías portarte mejor conmigo, Inés, porque yo he ganado la guerra, no sé si te acuerdas." (Grandes, 2010, p. 135). Garrido treats Inés as a comfort woman, yet still "Othering" her as a women on the leftist side, the antithesis of the decent women; he harasses her to have sex with him, bullying her and mistreating her psychologically, with the goal of the total humiliation of his victim, telling her things such as:

\begin{abstract}
En nuestra zona, las chicas iban a misa, rezaban el rosario, tejían jerséis y escribian cartitas ñoñas a los soldados, pero vosotras no, vosotras no perdíais el tiempo en esas tonterías... Vosotras erais de todos, de la causa, para eso habiais superado la superstición del matrimonio, el prejuicio de la decencia, y estabais todo el día calientes, porque había que recompensar a los héroes del pueblo, tenerlos contentos, ¿no?, aunque a los jefazos los trataríais mejor, seguro. Dime una cosa, Inés, cuando se la chupabas a tu responsable politico, ¿te ponías de rodillas? (Grandes, 2010, p. 135)
\end{abstract}

It is relevant to make a parenthesis here in order to mention the different forms of rape perpetrated by men as soldiers that Enloe reflected in the fourth chapter of Maneuvers. One form is the rape by a male soldier of a woman soldier in the same army, perhaps because he resents her presence in a previously all-male unit or because he is angry at her for her unwillingness to date him or flirt with him. Other cases are the rapes of women held in military prisons by male soldiers serving as guards; rapes perpetrated by a soldier acting as an interrogator with the apparent purpose of forcing the woman victim to give information. Grandes intertwines both cases on the previous quote. However, since those forms of rape could have been omitted by the main character as an attempt to preserve her dignity, while studying the case of Garrido's sexual harassment towards Inés, it is necessary to consider Eisenstein's idea of rape as part of nationalist and colonialist capture. This reflection was originally developed by W.E.B Dubois, who stated that rape continues to function as a symbol of conquest and nation building. This is precisely Garrido's goal, as Inés finds out his game:

No pretendía conquistarme, sino rendirme, hacerme capitular, claudicar, entregarme a él sin condiciones, y por eso renunciaba a vencer en las batallas que él mismo planteaba. No quería violarme, abusar de mi debilidad, disfrutar de mi cuerpo, no, aspiraba a mucho más. Lo que quería era volver a ganar la guerra, y ganarla en mí, tomar posesión de una mujer vencida, humillada, sin dignidad, sin esperanza, sin respeto por sí misma. (Grandes, 2010, p. 138).

The racial oppression mentioned by W.E.B Dubois and Eisenstein links with the political oppression in Spanish postwar for the defeated, as we see in the case of the young girl Mercedes. Eisenstein connects this thought with the slavery system, since black women had no legal marriage, no legal family, and no legal control over children. Mercedes doesn't even know her last names, because her parents were married under the Republic, and therefore, their marriage is not valid anymore. The loss of identity suffered by Mercedes shows how marriages under the Republic were considered invalid in the postwar. It also shows how Franco's government took advantage of the leftist women by stealing their children, with the help of the Catholic Church, from their biological parents. There is a point where Inés doubts if it wouldn't be easier to fulfill Garrido's desires, in order to fight for her survival, but she couldn't stand see herself defeated again, establishing a comparison with the women she saw during the war in Madrid, that presented a double defeat:

\footnotetext{
Mujeres aniquiladas, vacías, tan huecas que ya no les quedaba ni siquiera espacio para el miedo, sentadas junto a hombres uniformados que las trataban como si fueran ganado, animales de compañía que acabaran de recoger por la calle y que agradecían los palos que se llevaban a cambio de tener algo que comer, un rincón bajo techo donde echarse a dormir por las noches. Era repugnante, daba asco y vergüenza, sobre todo vergüenza, porque aquellos cabrones eran de los nuestros, y eso me dolía más. (Grandes, 2010, p. 139)
}

The game ends when Garrido manages to stay alone with Inés at Ricardo and Adela's house. While pointing a 
gun at her, he batters her and forces her to pleasure him. At the while, Garrido continues humiliating Inés and showing surprise of her negative to please him sexually. Her disgust with him causes him great surprise, since her nature is that of a filthy roja, a condition equal to that of a prostitute: "Mira que eres tonta, hija mía. Te lo digo en serio, porque siendo tan puta como eres, y estando tan salida como estás, la verdad es que no lo entiendo -me ofreció la misma mano que me había derribado, pero preferí levantarme por mis propios medios y sólo logré hacerle sonreír-." (Grandes, 2010, p. 145.) It is important to notice that Garrido insists on forcing Inés to pleasure him while on her knees, to emphasize submission and defeat. For Garrido, this submission represents the sexual act by a Republican woman who lost the war, thus reaffirming him as a winner. On the other hand, the commanding officer Garrido qualifies Ines' dignity as "stupid." At the same time, he states "la violencia también tiene su encanto, sobre todo para el que manda, que aquí, evidentemente, soy yo" (Grandes, 2010, p. 145) recognizing that he is enjoying the situation and finding pleasure on it, reinforcing the idea of power involving the submission of someone else.

As it is well known, and as Inés herself affirms after this incident, "el terror es un recurso sumamente eficaz." Moreover, it continues to establish a reason that will link the representation of violence in the novel, normalized in the whole country during the Civil War and postwar period, with the state strategies to spread terror, generalizing the fear and silence among Spaniards. An example of this situation in the novel is Galán's surprise when they find a prison work crew with political inmates, all Republican, that refuse to join the maquis' fight and run away instead. This is a sample of the Francoist regime's repression, as Inés explains to a confused Galán:

Lo que te ha pasado no es tan raro, porque aquí nadie vive en paz. No estamos en un país pacificado, sino en un país ocupado. [...] Y tú no has estado aquí. No has visto cómo nos rompían todos los huesos, una vez, y otra, y otra más. Cinco años de palizas, uno detrás de otro, cinco años seguidos, y nosotros cada vez más encogidos, más pequeños, más cobardes. (Grandes, 2010, p. 252).

Subsequently, she attributes the fear of the inmates to the terror experienced during the war and immediate postwar. Inés reveals her perspective to Galán who had been in the concentration camp of Argelés, in France, before fighting against the Nazis. Following his internment, he returned to defeat Franco. Inés gives Galán a different perspective than that which he could see while in exile: the story of a Spain full of people that "habría dado cualquier cosa, media vida, por salir de aquí en el 39, y que tuvo que quedarse para abarrotar las cárceles, para escuchar sus sentencias de muerte, para dormir durante treinta años en una baldosa y media de suelo sucio, con el cuerpo lleno de heridas gangrenadas, comidas por la sarna." (Grandes, 2010, p. 254). The resistance of Francoist repression is thus inevitably connected with fear for a still skeptic Galán. Inés finds this completely natural: "¿Y cómo quieres que estén? Pues muertos de miedo, claro. ¿Cómo no van a tener miedo, si les han pegado tanto que ya no se acuerdan ni de quiénes son?" (Grandes, 2010, p. 254.) According to Lobo, those men who now refuse to join the cause that have fought to defend only a couple of years ago do so because of alienation. He affirms that Spain is no longer their country, due to their exile. This recalls the patriotic feeling of loss that Max Aub developed, while telling Galán: "Los españoles que nosotros conocimos ya no existen. Están todos muertos, o en la cárcel, o tienen tanto miedo que no saben ni cómo se llaman." (Grandes, 2010, p. 308) Considering the issue of state violence related to this fear, Walter Benjamin argues that it is not possible to separate violence from law; that all violence is either law-making or law-preserving. He also maintains that all law, however remote it may seem from its origins and the forces that maintain it, is latent violence: "Admittedly, military violence is in the first place used quite directly, as predatory violence, toward its ends." (Benjamin, 1996, p. 283). Therefore, it is violence itself which decides the ends for which is justifiable. This circle defines violence self-evidently as a natural means of achieving natural or legal ends. The part of the book with the most explicit use of violence connects with this idea, since is when the author makes references to the torture that political prisoners suffered during the interrogations. Indeed, Benjamin states that the forms of violence "are present in another institution of modern state, the police. True, this is violence for legal ends" (Benjamin, 1996, p. 286). The response the novel gives to this violence and more specifically, the response that communist leader Pasionaria proposes is joy against the adversity: In order to mask destiny, death, hunger, and fear they need "alegría para no venirse abajo, para no ablandarse, para no ceder al desánimo, para soportar las caídas, para caer con entereza, para aguantar la tortura con la boca cerrada en los sótanos de las comisarías" (Grandes, 2010, p. 316). However, Benjamin's goal is not to discuss the different forms of law but the foundational and fundamental role of violence. Specifically, he argues that violence legitimates the use of force by focusing on means and ends. Benjamin concludes by highlighting two kinds of related violence: one that creates the law and another that sustains it. However separate Benjamin sees these two forms of violence, both are based upon justified means for just ends. Then, Benjamin moves from what he calls mythical violence, that is, violence related to our classical past and the foundation of the law, to divine violence. This latter form of violence is one that neither upholds the law nor 
creates a state. Moreover, it is, outside of discourse and language. By introducing this new form of violence, Benjamin breaks from the dialectical opposition between violence that posits the law and violence that preserves it. It entails, instead, a sovereign act that lacks meaning or explanation because is not framed by the law. This can be applied to the state violence developed by the Francoist regime, since it attributed itself certain sovereignty through both the support of Catholic Church, and the representation of the order versus the chaos that Francoism tried to associate with the maquis. In fact, Franco's slogan was "Dios, Patria y Rey" and he liked to be called not only General, but also Generalísimo Francisco Franco, caudillo de España por la gracia de Dios. This nomenclature reinforced the divine nature of his position. For these reasons, we can affirm that Francoism pretended to have a divine right for using violence against those who were a menace for the construction of New Spain, as we can see in Inés y la alegría: "Pertenezco al Partido Comunista de España y no os voy a decir nada más. Alegría. Golpes. Alegría. Palizas. Alegría. Huesos rotos. Alegría. Quemaduras. Alegría. Descargas eléctricas en los genitales, en los pezones, en los labios, en las plantas de los pies." (Grandes, 2010, p. 316). In addition, this section showcases the terror and stoicism mentioned and promulgated by Pasionaria. There is an important contrast there that leads to a loss of identity for the enemy, communists in this case. The prisoners have been battered so much by Francoist police that they can't even pronounce their names properly:

"Me llamo... -y el nombre ya sólo se entiende a medias, porque con tantos huecos en las encías y los labios hinchados, abiertos, rojos como fresones, el detenido o la detenida no articula bien las sílabas-. Soy miembro del Partido Comunista de España y ya sabéis que no os voy a decir nada más." (Grandes, 2010, p. 316)

Not having a name is the clearest sign of the lack of identity, showing how Francoist repression through violence not only criminalized and dehumanized the enemy through its propaganda, but also alienated individuals until they lost their identity. Despite the effort to emphasize the violence exerted by Franco's regime, the novel shows a period with a relatively pacific resistance to the dictatorship. This might even be considered non-violence instead of anti-state violence, but this vision of the resistance is not accurate in a global context.

The power established by law-making violence threatens the law-breaker with law-preserving violence. But this threat is subject to fate, because the criminal (the maquis, in this case) might not get caught, and his or her 'violation' of the law threatens to become, in turn, a law-making violence. As a result, it is a challenge to existing power. Benjamin's concept can help to explain the Francoism repression against the losers and other people related to any resistance movement. However, if it is not just a matter of getting away with violence at an individual level and the challenge to existing power is self-conscious and victorious - as in a political revolution - then the contest can only begin again. Benjamin acknowledges possible forms of non-violent resolution of potential conflicts between people, but these are immaterial because they are not legal. As soon as they are codified by legal contract or treaty, they would again be subject to force.

\section{Conclusion}

The novel Inés y la alegria is an example of the state violence and control of the population during the Spanish immediate postwar. The fear that resulted in a pact of silence still remains today. Many people still refuse to talk, and many of those who choose to tell the silent story lock doors and windows and whisper to avoid being heard. However, the opposite result of such oppression can be worse: a society brain-washed by a Fascist and Catholic regime, whose power structures have been shaped on gender issues, on the basis of a strong patriarchal society. Talking with social workers in Spain, I have found many cases of women surprised to learn that violence and submissiveness are no longer the norm. Grandes is denouncing the Francoism and its repercussion to present-day democracy, which has been suffering from Stockholm syndrome since 1936. In order to do so, she uses her voice as the narrator of the chapters in parentheses to legitimize the spreading of the story, and to attempt the recovering of the voices of the defeated who couldn't tell their story. The author is trying to avoid what Julia Conesa feared. Member of Las Trece Rosas, a group of underage women that were political prisoners in Ventas and were executed in 1939, Conesa finished a letter to her mom the previous day of her execution with the sentence: "que mi nombre no se borre en la historia."

\section{References}

Alcalde, Carmen. (1996) Las mujeres en el franquismo. Barcelona: Flor del viento ediciones.

Barrenquero Texeira, Encarnación. (2010) Mujeres en la guerra civil y el franquismo: violencia, silencio y memoria de los tiempos difíciles. Málaga: Universidad de Málaga. 
Benjamin, Walter. (1996) "Critique of violence." Selected writings. Volume 1. 1913-1926. Cambridge: Harvard UP. $236-252$.

Cañil, Ana R. (2008) La mujer del maquis. Madrid: Espasa-Calpe.

Catalá, Neus. (2000) De la resistencia y la deportación: 50 testimonios de mujeres españolas. Barcelona: Península,

Cervera, Alfons. (1997) Maquis. España: Montesinos.

Colmeiro, José F. (2005) Memoria histórica e identidad cultural: De la postguerra a la postmodernidad. Barcelona: Anthropos.

Cuevas, Tomasa. (1998) Prison of women: testimonies of war and resistance in Spain, 1939-1975. Albany: State University of New York Press.

Di Febo, Giuliana. (1979) Resistencia y movimiento de mujeres en España: 1936-1976. Barcelona: Icaria.

Eisenstein, Zillah. (2004) Against empire: Feminisms, racism and the west. New York: Zed Books.

Enloe, Cynthia. (2000) Maneuvers: The international politics of militarizing women's lives. Los Angeles: University of California Press.

Gómez López-Quiñones, Antonio. (2006) La guerra persistente: Memoria, violencia, utopía: representaciones contemporáneas de la Guerra Civil española. Madrid: Iberoamericana Vervuert.

Gould Levine, Linda, y Feiman Waldma, Gloria. (1980) Feminismo ante el franquismo: Entrevistas con feministas de España. Miami: Ediciones Universal.

Grandes, Almudena. (2010) Inés y la alegría. Barcelona: Tusquets.

Herrmann, Gina. (2010) Written in red: The communist memoir in Spain. University of Illinois Press.

---. (2012) "Reenactments of Remedios Montero: Oral History of a Spanish Guerrillera in Testimony, Fiction, and Film". Eds. Antonio Gómez López-Quiñones and Carmen Moreno-Nuño. Armed resistance: Cultural representations of the anti-Francoist guerrilla. Volume 10.

---. (2003) "Voices of the vanquished: Leftist women and the Spanish Civil War". Journal of Spanish cultural studies.Vol. 4, No. 1.

Labanyi, Jo. (2009) "The language of silence: historical memory, generational transmission and witnessing in contemporary Spain." Journal of romance studies, 9. 23-35.

Moreiras Menor, Cristina. (2002) Cultura herida: Literatura y cine en la España democrática. Madrid: Libertarias.

Moreno Gómez, Francisco. (2001) La resistencia armada contra Franco. Tragedia del maquis y la guerrilla. Barcelona:Editorial Crítica.

Moreno-Nuño, Carmen. (2001) "La representación del maquis en la historia del cine español: De bandoleros a guerrilla antifranquista." Letras peninsulares 16.1 (Spring 2003): 353- 70.

Muñoz Molina, Antonio. (2001) Sefarad. Madrid: Suma de letras.

Osorio, Elsa. (2012) La capitana. Madrid: Siruela.

Pérez, Janet and Ihrie, Maureen. (2002) The feminist encyclopedia of Spanish literature. Westport: Greenwood Press.

Romeu Alfaro, Fernanda. (2002) El silencio roto: Mujeres contra el franquismo. Madrid: El viejo topo.

Serrano, Secundino. (2001) Maquis: Historia de la guerrilla antifranquista. Madrid: Temas de Hoy.

Trapiello, Andrés. (2001) La noche de los cuatro caminos: Una historia del maquis. Madrid: Aguilar.

Tusquets, Esther. (2008) Habíamos ganado la guerra. Barcelona: Bruguera.

Yusta Rodrigo, Mercedes. (1996) "La historia en femenino singular: Las fuentes orales en el estudio del maquis en España." Ed. José Manuel Trujillano Sánchez and Pilar Díaz Sánchez. V Jornadas historia y fuentes orales. Ávila: Universidad Complutense de Madrid. 241-52. 